\title{
Salvadoran economic transnationalism: embedded strategies for household maintenance, immigrant incorporation, and entrepreneurial expansion ${ }^{1}$
}

\author{
PATRICIA LANDOLT
}

\begin{abstract}
This article presents a case study of the transnational economic practices linking two Salvadoran settlements in the United States and El Salvador. It considers the relationship between economic transnationalism, immigrant settlement and economic development in the country of origin. Four processes are examined including: (1) the creation of border-spanning social networks by migrants and their home country counterparts; (2) the construction of transnational economic activities and institutions; (3) the broader transnational social formations in which these are embedded; and, (4) the cumulative and unintended consequences of economic transnationalism for migrant households, the immigrant community, and El Salvador. The article applies the concepts of social network, social capital, and embeddedness, to explain the sources and determinants of individual- and community-level variation in types of transnational economic practices. The conclusions drawn are that economic transnationalism is both part of a transnational settlement strategy and holds potential for economic development in the country of origin.
\end{abstract}

First forged by refugees fleeing political violence in the late 1970s, circuits of transnational obligations and interests have proliferated and now link together a broad spectrum of Salvadoran society across the borders of multiple nation states. Over the course of close to three decades, border-spanning social networks have moved beyond the household sphere to include a variety of institutions such as enterprises, political parties, charitable organizations, and youth groups. Migrants' increasingly strategic participation in home country affairs has also prompted a policy response from the Salvadoran state and a reorientation of business plans by some sectors of private enterprise. Such contact and interaction has consolidated an elaborate series of transnational social arrangements and institutions (Landolt et al. 1999; Landolt 2000; Lungo 1997; Mahler 1995; Menjívar 2000).

In this article, I draw on primary data from a multi-sited project on the causes and consequences of migrant transnationalism to explore the economic dimensions of Salvadoran transnational migration. I focus on two themes. First, I examine the relationship between economic transnationalism and immigrant settlement. Immigrant settlement involves a multiplicity of processes including labour market insertion, ethnic identity formation, and the acquisition of citizenship rights. Prevailing interpretations portray settlement as a process that involves a break with home 
country life and hence is largely shaped by conditions in the host country. The concept of transnational settlement suggests that the struggle for incorporation and adaptation takes place within a framework of interests and obligations that results from migrants' simultaneous engagement in the home and host country. I consider to what extent the border-spanning economic activities undertaken by Salvadoran migrants constitute part of a transnational settlement strategy.

Second, I analyse the cumulative and unintended consequences of economic transnationalism for migrant households and economic institutions in the sending and receiving country. I am particularly interested in the relationship between transnational strategies of household reproduction, migrant entrepreneurship and the business landscape of El Salvador. I examine the ways in which migrant economic transnationalism prompts a variety of economic actors in El Salvador to reorient their investment and growth strategies.

The article makes a contribution to the growing scholarship on transnationalism and expands the field of relevance of economic sociology. It theorizes the relationship between economic transnationalism and immigrant settlement and builds a typology of transnational economic activities and institutions. It also 'advances certain frontiers of economic sociology' (Merton 1995: vii) by drawing on concepts such as social capital and embeddedness to analyse the dynamics of economic transnationalism.

The article is organized into five sections. The first section reviews the literature on transnational migration to frame the analysis of Salvadoran economic transnationalism. In turn, presentation of the case study is organized around four analytically distinct, but empirically interwoven, moments including: (1) the creation of border-spanning social networks by migrants and their home country counterparts; (2) the construction of transnational economic activities and institutions; (3) the broader transnational social formations in which such activities and institutions are embedded; and, (4) the cumulative and unintended consequences of economic transnationalism for migrant households, the immigrant community and El Salvador. The concluding section summarizes and theorizes the findings.

Before proceeding, a methodological note on data collection is required. The data presented in the article are drawn from a comparative study of the causes and consequences of the emergence of transnational communities among Latin American immigrants in the United States. The cross-country study was conducted under the direction of Alejandro Portes of Princeton University and Luis Eduardo Guarnizo of the University of California, Davis. In the period between 1996 and 2000, three phases of data collection were carried out on three target populations, including Colombians, Dominicans and Salvadorans. For each target population, data collection was undertaken in two settlement cities and the country of origin using the same set of survey instruments and sampling designs in each case.

In 1996, the first phase of data collection on the Salvadoran case was launched. It involved guided interviews with key informants in Washington, DC, Los Angeles, and El Salvador. A purposive sampling technique was used to select informants who were either representative of the population under study or who had expert knowledge of Salvadoran migration (Singleton et al. 1993). In the USA, informants included entrepreneurs, community leaders, municipal officials, immigration lawyers, journalists and radio personalities. In El Salvador interviews were undertaken with national and municipal government officials, political party representatives, business leaders, 
members of the clergy, academics, and return migrants. In total, 36 interviews were conducted in the Los Angeles area and 26 in Washington, DC. In El Salvador, 33 interviews were conducted in the capital city of San Salvador and 30 were completed in the secondary city of San Miguel and the surrounding rural areas.

In 1998, a second phase of research was undertaken in Los Angeles and Washington, DC that involved two forms of data collection. First, a semi-structured interview was applied to transnational actors using a purposive or snowball sampling method, where a transnational actor is defined as an individual engaged in an activity that extends beyond the household and which requires regular contact between El Salvador and its migrant settlements. A process of chain referrals was used in which transnational actors were asked to provide the names of others in the target population, who were then contacted, interviewed, and asked to name others and so on. Interviews with transnational actors gathered information about their employment and migration history, as well as data on the nature of their contacts with El Salvador. In total, 84 confirmed transnational actors were interviewed in Los Angeles and 94 in Washington, DC.

Second, a general survey was applied to heads of households using a multi-stage cluster sampling technique. The three-step sampling process began with the selection of census tracts of Salvadoran concentration. Street blocks were randomly selected from these tracts and finally households were solicited from among these based on a systematic counting method. The survey obtained demographic information and migration and employment histories. It also gauged the nature and regularity of a respondent's contact with El Salvador. The structured survey of a random sample of Salvadoran heads of households served as a comparative point of reference for the semi-structured interview applied to transnational actors. It guaranteed that data collection did not sample only the dependent variable, namely confirmed transnational actors. One-hundred-and-fifty-six heads of households were interviewed in Los Angeles and 139 in Washington, DC.

In 2000, a third phase of data collection was undertaken in El Salvador. A purposive sampling technique was used to survey confirmed transnational actors using a semi-structured interview that paralleled the one applied to transnational actors in the United States. The research team interviewed a range of economic, social, and political transnational actors in a variety of urban and rural settings of El Salvador. Name-generators developed in Phase 1 (1996) and Phase 2 (1998), as well as a third, independent name-generator developed in Phase 3 (2000) were used to build a list of 300 potential informants of whom 186 were interviewed using the semistructured survey questionnaire.

\section{Theorizing transnational migration}

In the 1970s, the Fordist regime of accumulation began to collapse and was slowly reorganized into a system of flexible accumulation (Harvey 1989). Several features distinguish the latest incarnation of the international capitalist system including: an unparalleled growth in the intensity, scope and volume of international capital flows (Sklair 1999); the fragmentation of the industrial production process into a spatially dispersed, global assembly line, with labour-intensive aspects of production located in the Third World, and planning, product design, and management concentrated in 
strategic urban centres (Nash and Fernández-Kelly 1983; Sassen 1991); the concomitant diffusion of space-time compressing technologies (Harvey 1989); and, a new regulatory regime for capital flows governed by global institutional actors (Sassen 1996; Sklair 1999).

In turn, world society has experienced a monumental increase in the cross-border flows of everything as well as a proliferation of transnational practices and processes that emerge in the interstices of the new global economy. Transnationalism broadly involves the development and maintenance of ties and interactions that link people, communities, and institutions across the borders of nation-states (Vertovec 1999: 447). Transnational processes simultaneously transcend and join together multiple locations across one or more nation-states (Basch et al. 1994; Kearney 1995). This widening, deepening, and speeding up of worldwide interconnectedness (Held et al. 1999) has intensified established migration patterns and led to the emergence of novel trends and practices (Massey et al. 1998). In particular, there is a growing tendency among migrant populations to avail themselves of space-time compressing technologies in order to forge complex social arrangements that link together their places of origin and settlement.

A group of social anthropologists led by Nina Glick Schiller and Linda Basch (Basch et al. 1994; Glick Schiller at al. 1992) first identified migrant transnationalism as: 'the process by which transmigrants, through their daily life activities forge and sustain multi-stranded social, economic, and political relations that link together their societies of origin and settlement, and through which they create transnational social fields that cross national boundaries' (Basch et al. 1994: 7, 27). They emphasized the newness of the phenomenon and heralded the emergence of the transmigrant as a new social actor. A series of celebratory claims regarding the novelty and inherently radical logic of transnationalism ensued that remain central to debates in the field.

Rather than a completely novel phenomenon, what distinguishes contemporary transnationalism is best captured by the axiom: a quantitative change results in a qualitative difference in the order of things. There is an order of transnational practices that have historically gone hand-in-hand with migration and are seen among nineteenth-century immigrants. Then, as now, migrants remitted funds to assist kin, invested at home, sometimes returned to start a business, and engaged in home country politics (Daniels 1990; Foner 1997; Jones 1976). Late-twentieth century transnational migration thus exhibits an expansion in the realm of what is possible, the scope of who can do it, and in the complexity and consequences of what is done.

First, once largely the purview of elite actors, transnational practices have become a mass phenomenon (Portes 1999a). The exponential increase in the proportion of migrants who sustain transnational social relations is suggested by the global increase in migrant remittances. World remittances were calculated at US $\$ 43.3$ billion in 1980, US $\$ 65.6$ billion in 1989, and US\$71.1 billion by 1990 (Stanton-Russell 1992). Between 1991 and 1996, international money transfers from the United States grew an estimated 20 per cent. Migrant remittances to Mexico and select countries of Central America increased from US\$1 billion in 1980, to US\$3.78 billion in 1990, to US $\$ 8$ billion in 1998 (Orozco 2000). Despite their proliferation, it is erroneous to assume that all migrants participate equally in transnational exchanges. What then are the sources and determinants of variation in the types of transnational ties maintained by individuals within an immigrant community? 
Second, readily available space-time compressing technologies, such as cell phone, fax and e-mail communications, enable transnational exchanges to take place in real time. New technologies grant an unparalleled ease and intensity to such relations and, thus facilitate the consolidation of complex border-spanning arrangements and institutions. While the diffusion of technologies explains how a greater range of people is able to maintain stable transnational relations and forge complex institutions, it does not explain why they do so. What determines that an immigrant group or migrant household avails itself of these instruments?

Finally, the volume and institutional complexity of transnational practices prompts a series of often unexpected outcomes. Transnational concerns, rooted in the household, serve migrants as a point of departure for deepening engagement in the political and economic affairs that they deem relevant (Basch et al. 1994; Portes et al. 1999b), which typically includes a combination of home and host country issues (Landolt 2000; Popkin 1999). Moreover, the economy of the sending country comes to depend increasingly on migrant remittances, while the receiving country government must contend with the transnational concerns of a growing proportion of its citizens. Overtime, the border-spanning activities of a migrant population thus lead to a reformulation of state policies and a reorientation of capital accumulation strategies. The institutional bridge that links migrants with their country of origin does not appear overnight. What factors shape the formation and characteristics of such a reorientation of policy and what is the impact on the migrant population and more precisely on their economic condition?

Drawing from economic sociology and the above discussion, the article develops three propositions that interpret economic transnationalism as a process conditioned by contexts and grounded in locations. First, given propitious structural conditions for the proliferation of transnational ties, historical and contextual factors combine to prompt a migrant population to forge transnational social networks and in turn contour the attributes of such arrangements. Despite a common context of strong ties to El Salvador, the evidence suggests a great deal of variation both in individual and household-level transnational economic practices and in the dynamics of economic transnationalism across different locations in the USA and El Salvador. In this light, the second proposition explored is that such individual-level differences can be explained in part by the structure of personal networks, the sources of social capital under girding resource exchanges, and the quality of the actual resources mobilized (Portes and Sensenbrenner 1993; Portes 1998). ${ }^{2}$ Similarly, the third proposition is that the character of transnational economic institutions is shaped by the broader economic and political structures and distinct locations in which they are embedded (Granovetter 1985).

\section{The creation of transnational social networks}

El Salvador has a century-old tradition of cyclical labour migration. Since the 1880s, the agro-export economy has expropriated and concentrated landholdings, generating a landless rural semi-proletariat dependent, but marginal, to the cash economy (Vilas 1995). As a result, a large population of rural workers has always been forced to migrate seasonally to wage work in coffee growing highlands and plantation lowlands. Thus, for example, in the 1920s, Salvadorans began migrating to Honduras, an agricultural frontier region that offered both wage-work on plantations and empty 
lands for subsistence cultivation. At the turn of the twentieth century, Salvadorans were recruited to work on the construction of the Panama Canal. One hundred thousand Salvadorans had migrated to Honduras in 1949 and by the 1960s the number had reached 350,000 (Vilas 1995). Salvadorans also began migrating seasonally to the coastal plantations of Guatemala, where, by the 1960s, they constituted 10 per cent of the agricultural labour force. In the 1940s, labour migration to the USA also gained force temporarily as Pacific Coast shipyards and industries recruited Salvadorans to compensate for the wartime labour shortage (Córdoba 1995).

In the 1980s, this largely regional labour migration system was ruptured by the civil war. Political violence overturned established migration patterns and led to a refugee exodus. Warfare transformed the structural process of dislocating rural people into one of forcibly displacing them (Edwards and Siebentritt 1991; Zolberg et al. 1989). During the civil war, 80,000 people were killed and 30 per cent of the national population, estimated at five million in 1980, was displaced from its place of origin. Twenty per cent of the displaced left El Salvador. Approximately 450,000 Salvadoran refugees settled in Central America. Canada and Australia recognized El Salvador as a refugee-producing country and granted asylum to thousands of families (Ferris 1987). Approximately 250,000 Salvadorans settled in Mexico (Aguayo and Weiss Fagen 1988), but the lion's share of Salvadorans migrated to the United States. It is estimated that 1.2 million Salvadorans now live in the USA, with major settlements in Los Angeles, San Francisco, Washington, DC, and the New York City area.

A combination of historical and contemporary conditions of exit from El Salvador and entrance into the United States has shaped Salvadoran settlement. In El Salvador, the tradition of seasonal labour migration transformed the rural household into a malleable economic unit able to adjust to migration cycles. Migrants are temporarily freed from the family economy so that they may contribute to its maintenance (Wood 1981). ${ }^{3}$ Over time, this economic strategy has also become a normative framework of expectations ruled by the idea that, whether to local plantations or global cities, migration is temporary and migrants have continuing obligations to non-migrant kin.

In extreme conditions, such as warfare, normative expectations are likely to be heightened. Indeed, during the civil war, Salvadorans consistently constructed a socially expected duration ${ }^{4}$ of temporary migration and the migrant as a sojourner destined to return. Table 1 shows that, upon arrival in the USA, more than 66 per cent of migrants planned to return to El Salvador. Migrants who arrived at the height of the war (1980-1984) have the highest rate of expected return (71.5 per cent). Fifty-five per cent of families, namely those remaining in El Salvador, also expected migrant kin to return. Again, family expectations of a permanent return were highest for the cohort that migrated between 1980 and 1984 (59 per cent).

In turn, Salvadorans' entrance into the USA was shaped by contextual factors such as the responses of the US government and civil society, labour market opportunities, and the group's own resources (Portes and Rumbaut 1996). Salvadoran settlement played out like a battle between a hostile federal government and a broad spectrum of progressive grassroots organizations. The Reagan administration supported a military solution to the conflict in El Salvador. In order to guarantee continued Senate approval of military funding for the Salvadoran government, the Executive refused to recognize Salvadorans as legitimate refugees. To do so was to affirm that the Salvadoran state was unwilling to protect the human and civil rights of its citizens. 
Table 1: socially expected durations: migrant plans and family expectations

\begin{tabular}{|c|c|c|c|c|c|c|c|c|c|c|c|c|}
\hline \multirow[b]{2}{*}{ Plans } & \multicolumn{2}{|c|}{ Before 1980} & \multicolumn{2}{|c|}{ 1980-84 } & \multicolumn{2}{|c|}{$1985-89$} & \multicolumn{2}{|c|}{ After 1990} & \multicolumn{2}{|c|}{ Initial plans } & \multicolumn{2}{|c|}{ Current plans } \\
\hline & Initial $^{a}$ & Current & Initial & Current & Initial & Current & Initial & Current & Total & $\mathrm{N}$ & Total & $\mathrm{N}$ \\
\hline Stay here & 31.1 & 51.1 & 20.8 & 56.6 & 27.9 & 63.3 & 14.3 & 38.5 & 23.7 & 112 & 54.1 & 255 \\
\hline Return & 61.1 & 35.6 & 71.5 & 31.5 & 66 & 22.4 & 67 & 38.5 & 66.9 & 316 & 30.8 & 145 \\
\hline Don't know & 7.8 & 13.3 & 7.6 & 11.9 & 6.1 & 14.3 & 18.7 & 23.1 & 9.3 & 44 & 15.1 & 71 \\
\hline Total & $100 \%$ & $100 \%$ & $100 \%$ & $100 \%$ & $100 \%$ & $100 \%$ & $100 \%$ & $100 \%$ & $100 \%$ & & $100 \%$ & \\
\hline $\mathrm{N}$ & 90 & 90 & 144 & 143 & 147 & 147 & 91 & 91 & & 472 & & 471 \\
\hline \multicolumn{13}{|c|}{ Family's expectations upon departure and currently } \\
\hline & \multicolumn{2}{|c|}{ Before 1980} & \multicolumn{2}{|c|}{$1980-84$} & \multicolumn{2}{|c|}{$1985-89$} & \multicolumn{2}{|c|}{ After 1990} & \multicolumn{2}{|c|}{ Initial plans } & \multicolumn{2}{|c|}{ Current plans } \\
\hline & Initial & Current & Initial & Current & Initial & Current & Initial & Current & Total & $\mathrm{N}$ & Total & $\mathrm{N}$ \\
\hline $\begin{array}{l}\text { Return } \\
\text { permanently }\end{array}$ & 48.9 & 16.7 & 59 & 25 & 56.2 & 26.5 & 52.7 & 37.4 & 55 & 259 & 26.3 & 124 \\
\hline $\begin{array}{l}\text { Return to } \\
\text { visit }\end{array}$ & 35.6 & 63.3 & 229 & 535 & 336 & 592 & 264 & 462 & 293 & 138 & 557 & 263 \\
\hline Never return & 11.1 & 15.6 & 9 & 11.8 & 6.2 & 10.2 & 8.8 & 6.6 & 8.5 & 40 & 11 & 52 \\
\hline Other & 4.4 & 4.4 & 9 & 9.7 & 4.1 & 4.1 & 12.1 & 9.9 & 7.2 & 34 & 7 & 33 \\
\hline Total & $100 \%$ & $100 \%$ & $100 \%$ & $100 \%$ & $100 \%$ & $100 \%$ & $100 \%$ & $100 \%$ & $100 \%$ & & $100 \%$ & \\
\hline $\mathrm{N}$ & 90 & 90 & 144 & 144 & 146 & 147 & 91 & 91 & & 471 & & 472 \\
\hline
\end{tabular}

a 'Initial' means plans or expectations at the time of the migrants' initial arrival in the United States.

Source: Comparative Immigrant Enterprise Project, 1998

The Central America Solidarity Movement (CACM), on the other hand, mobilized for refugee rights and a balanced immigration policy (Gosse 1988; MacEoin 1985). The movement made a clear link between US foreign policy and immigration policy. It was their belief that as long as the government funded the military campaigns of undemocratic regimes, the USA would have a responsibility to offer safe haven to the victims of the resulting conflicts. In the long-term, the CACM contributed to the formation of an alternative policy agenda that granted Salvadorans a modicum of legal recognition. ${ }^{5}$ Yet the short-term impact of the federal administration's position on El Salvador was devastating. Denied refugee status, Salvadorans lived in constant fear of deportation, entered the USA surreptitiously, and only applied for asylum once apprehended by the INS. As a result, an estimated 50 per cent of the Salvadoran population remains undocumented or has only a temporary visa (López et al. 1997).

The economic context of reception faced by Salvadorans was equally troubling. In the USA, industrial restructuring caused a reduction in unionized blue-collar jobs and 
a casualization and informalization of work (Sassen 1991). Salvadorans, who came with few resources, were concentrated in the unregulated, low-wage service sector and had little hope of finding more stable and better-remunerated employment. In Los Angeles, Salvadorans worked as domestic workers, sewing operators, construction workers, gardeners, and painters (López et al. 1997). Similarly, in Washington, DC, they worked in construction, landscaping, restaurants, cleaning and maintenance, and as domestic workers (Landolt 2000; Repak 1995).

The combination of normative expectations of a temporary migration, continuing obligations to non-migrant kin and the need for minimal guarantees in the face of legal and economic uncertainty in the USA prompts the transnational allocation and management of resources. Under ideal circumstances, remittances and investments in El Salvador allow migrants simultaneously to protect themselves, safeguard their economic assets, and exercise their obligations to non-migrant kin.

Table 2 shows that the overwhelming majority of survey respondents ( 82 per cent) remit cash on a regular basis. Fifty-six per cent remit at least once a month, and 22 per cent do so every three to six months. The table also shows that 40 per cent of respondents own real estate in El Salvador. Seventy per cent of owners have family making use of the property.

Table 2: transnational household economic strategies

\begin{tabular}{|c|c|c|c|}
\hline \multicolumn{2}{|c|}{ Remittances \% } & \multicolumn{2}{|c|}{ Home ownership \% } \\
\hline \multicolumn{2}{|l|}{ Sends remittances: } & \multicolumn{2}{|c|}{ Owns real estate in El Salvador: } \\
\hline Yes & 82.0 & Yes & 39.3 \\
\hline No & 18.0 & No & 60.7 \\
\hline Total & 100.0 & Total & 100.0 \\
\hline $\mathrm{N}$ & 473 & $\mathrm{~N}$ & 473 \\
\hline \multicolumn{2}{|c|}{ Frequency of remittances [remitters only]: } & \multicolumn{2}{|c|}{ Number of properties owned [proprietors only]: } \\
\hline Once a month or more & 56.7 & 1 & 70.8 \\
\hline Once every three months & 22.5 & 2 to 5 & 27.0 \\
\hline Every six months to a year & 12.4 & More than 6 & 2.2 \\
\hline Infrequently & 8.3 & & \\
\hline Total & 100.0 & Total & 100.0 \\
\hline $\mathrm{N}$ & 386 & $\mathrm{~N}$ & 185 \\
\hline \multicolumn{2}{|c|}{ Annual amount of remittances [remitters only]: } & \multicolumn{2}{|c|}{ Use of properties [proprietors only]: } \\
\hline Less than US\$100 & 7.6 & Occupied by family & 69.6 \\
\hline$\$ 100-\$ 500$ & 24.4 & Rented & 11.4 \\
\hline$\$ 500-\$ 1000$ & 26.2 & Vacant until return & 12.5 \\
\hline$\$ 1000-\$ 3000$ & 29.0 & Other & 6.5 \\
\hline$\$ 3000-\$ 6000$ & 9.8 & & \\
\hline$\$ 6000$ or more & 3.0 & & \\
\hline Total & 100.0 & Total & 100.0 \\
\hline $\mathrm{N}$ & 386 & $\mathrm{~N}$ & 184 \\
\hline
\end{tabular}

Source: Comparative Immigrant Enterprise Project, 1998. 
Moreover, the aggregate flow of remittances to El Salvador has increased steadily since the 1970s. In fact, annual remittances were estimated at US\$600 million in 1980, US $\$ 700$ million in 1988, and had reached US $\$ 1.26$ billion by 1996 (Caribbean Update 1996). The ratio of Salvadoran workers' remittances to the country's export of goods, services and income was 0.8 per cent in 1980, 17.6 per cent in 1990, and had reached 47 per cent in 1996 (Itzigsohn 2001).

A unique set of historical and contextual factors thus contour Salvadoran transnationalism. Salvadoran migration begins as the refugee exodus of a resource poor population. In the USA, the existing Salvadoran population was small and did not constitute a community able to offer assistance to the newly arrived refugee population. As a result, moral and economic obligation to families left behind, but also fear and distrust of the local situation are prevailing concerns that conditioned social interactions. In this context, border-spanning relations begin with the household and specifically as a strategy for social reproduction and resource management. Migrant households thus acquire a distinctly transnational field of vision for economic decision-making. The next section examines how household-level social networks form the basis for the formation of income-earning transnational activities and institutions.

\section{The construction of transnational economic institutions}

Drawing from existing scholarship, three features of transnational economic activities and institutions are noted. First, transnational institutions and activities 'require regular and sustained social contacts over time across national borders for their implementation' (Portes et al. 1999a: 219). Second, like any institution, they are socially constructed and thus are forged by the mobilization of resources through social networks and conditioned by the broader social structure in which they are embedded (Granovetter 1993). Finally, transnational enterprises (TEs), like transnational corporations (TNCs), realize a profit based on the price differentials created by national borders. They are thus argued to constitute part of a grassroots response to the globalization of capital accumulation (Portes 1999b). What clearly distinguishes TEs from TNCs is that the former have no power over the global regulatory schemes that frame capital flows.

There are an endless variety of transnational income-generating activities that link together El Salvador and its migrant settlements in the United States. Table 3 present a tally of the types of entrepreneurial activities captured in the surveys conducted in Los Angeles, Washington, DC, and El Salvador. In El Salvador, the most common economic ventures are retail commerce ( 24 per cent), financial services ( 23 per cent), small-scale manufacturing (14 per cent) and personal services (13 per cent). In the United States, Salvadoran enterprises are concentrated in retail (40 per cent) and personal services (35 per cent).

Table 4 presents data on the characteristics of transnational enterprises. In the USA, the majority of Salvadoran businesses are individually owned (69 per cent). Only 19 of the 126 firms surveyed have employees in El Salvador. While there is some variety in firms' monthly sales, the sample appears to be skewed towards large firms with monthly sales of more than US $\$ 20,000$ (42 per cent). This probably corresponds to Salvadoran corporations that have established branch plants in migrant 


\section{Patricia Landolt}

settlements. In El Salvador, 38 per cent of firms are individually owned, 25 per cent are family businesses, and 33 per cent have been established by two or more business partners. Fifty-one per cent of transnational firms in El Salvador have monthly sales of less than US\$2000. Fifty-five per cent are micro-enterprises with less than ten employees and only 13 of the 124 firms surveyed in El Salvador have employees in the United States.

Table 3: transnational enterprises in El Salvador and the United States

\begin{tabular}{lcc}
\hline Economic activity & El Salvador $\%$ & United States \% \\
\hline Investments in land & 6.5 & 3.2 \\
Small-scale manufacturing & 14.5 & 7.9 \\
Transportation & 4.0 & \\
Communications & 8.1 & 3.2 \\
Wholesale commerce & 3.2 & 1.0 \\
Retail commerce & 24.2 & 40.4 \\
Financial services & 23.4 & 8.7 \\
Hotels, lodging & 2.4 & \\
Personal services & 13.7 & 35.7 \\
Total & 100.0 & 100.0 \\
N & 134 & 126 \\
\hline
\end{tabular}

Source: Comparative Immigrant Enterprise Project, 1998, 2000

Table 4: transnational firms in El Salvador and the United States

\begin{tabular}{lcc}
\hline & El Salvador \% & USA \% \\
\hline Type of ownership: & 38.8 & \\
Individual & 25 & 69.1 \\
Familiar & 33.8 & 20.0 \\
Partnership & 2.5 & 10.9 \\
Cooperative & 100 & \\
Total & 80 & 100 \\
$\mathrm{~N}$ & & 110 \\
\hline Monthly sales in US\$: & & \\
Fewer than 2000 & 51.2 & 12.1 \\
2001 to 5000 & 18.6 & 8.1 \\
5001 to 10,000 & 9.3 & 21.2 \\
10,001 to 20,000 & & 16.2 \\
More than 20,000 & 20.9 & 42.4 \\
Total & 100 & 100 \\
N & 43 & 99 \\
\hline
\end{tabular}


Table 4 (continued)

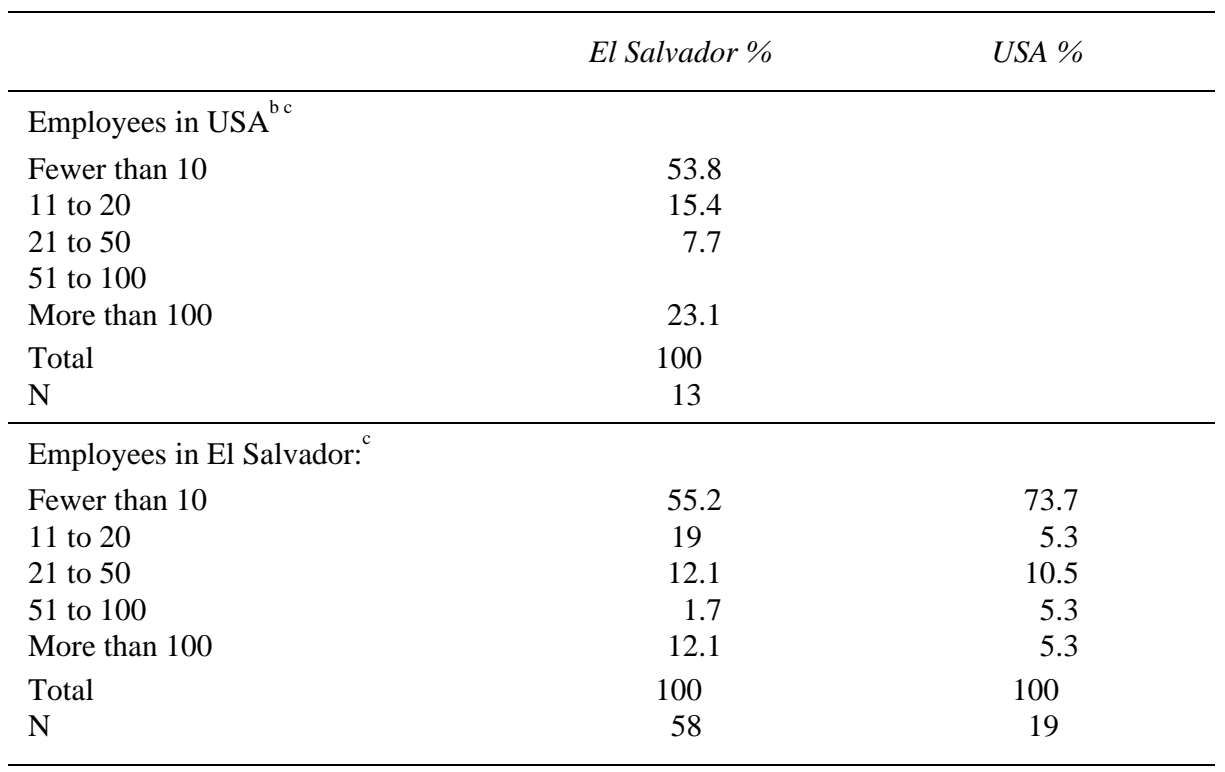

a Limited to firms reporting this information.

b Limited to firms based in El Salvador.

c Limited to firms with employees.

Source: Comparative Immigrant Enterprise Project, 1998, 2000.

Bibliographic sketches complement the above inventory and shed light on the broader context in which actors engage in border-spanning entrepreneurial ventures. ${ }^{6}$

Case 1: Olga Zelaya, who has lived in Washington, DC since childhood, worked in a restaurant for 12 years and studied business administration in a local community college. Olga recently started her own restaurant, which serves typical Salvadoran food. While her business and household obligations are centred in the USA, she gets her menus, place mats and napkins printed in El Salvador and periodically raises funds for her hometown church.

Case 2: Tomás Aguilar has lived in Los Angeles since 1987 and is a US citizen. He runs a law office that specializes in legal services required by Salvadoran migrants, such as immigration procedures and property titles in El Salvador. He works with his brother Luis, a lawyer and notary public in El Salvador, who conducts all of the necessary legal procedures in the Salvadoran court system and travels to LA every three months.

Case 3: Carlos Antonio is 55 years old, has an elementary school education, and lives in the cantón of Las Tunas in the department of La Unión. ${ }^{7}$ For the last eight years, he has travelled regularly to Washington, DC to visit his brother Julio. In 1999, Carlos Antonio, along with Julio and Armando, a 
migrant compadre ${ }^{8}$ from the cantón, who also lives in DC, founded a bean exporting business. Carlos Antonio purchases beans in the nearby department of San Vicente and contracts about ten people in Las Tunas to clean and package the product. Julio and Armando are in charge of marketing. For the time being, the owner of a Salvadoran grocery store, another member of the Las Tunas community, has agreed to carry their product in his store.

Case 4: Jaime García is 58 years old. He lived in the USA for seven years where he studied restaurant management, returned to El Salvador in 1968, and now owns a chain of restaurants with locations in San Salvador, Los Angeles, and San Francisco. Mr García has two Salvadoran business partners who manage the US restaurants. He also travels regularly to oversee things and estimates that 80 per cent of profits now come from the two US restaurants.

Case 5: Agustín is 33 years old. He lived undocumented in New York City for nine years, where he worked as a carpenter. In 1994, Agustín returned to El Salvador and used his savings to start a carpentry business. He called on kin living in New York City, Houston, Los Angeles, and Miami to drum up business for him in the Salvadoran migrant community. He now gets orders for furniture and woodwork from Salvadorans in the USA and from migrants visiting the country and estimates that the migrant market accounts for 10 per cent of sales, which average US\$4,500 a month.

Case 6: In 1995, after living in Virginia for 20 years, Ana and her husband José, both in their fifties returned to their hometown of Santa Rita. Ana brought back kitchen equipment and now runs a small breakfast and lunch diner. José brought back a pick-up truck that he rents out. Ana is bored, misses her children who are in the USA, and is worried about their financial situation since she does not consider Santa Rita a good place to set up a business. As she explains, the town's working age population has been migrating to Washington, DC for the last 25 years. Local residents are either very old or very young, receive remittances for basic expenses, and have little disposable income.

Case 7: Juan Segura has lived in Washington, DC for five years and was recently hired as the East Coast representative for the Constancia Bottling Company, a Salvadoran brewery. Beginning in the 1990s, the Constancia conducted a market study that mapped the location of all major Salvadoran settlements in the United States and began targeting the migrant market. In Washington, DC and Los Angeles, the Constancia sponsors and often makes monetary or in-kind donations to Salvadoran community fundraisers. For Christmas, the company offers a five-minute calling card to El Salvador with every six-pack of beer. In DC, Juan Segura courts the Salvadoran market by attending community functions, sponsoring fundraising events, and generally keeping in touch with key figures in the community.

The tally of activities surveyed and the bibliographic sketches suggest that Salvadoran transnational enterprises vary along three dimensions. One dimension is the degree to 
which financing, production inputs and markets for an enterprise are garnered through the circuit linking El Salvador and its migrant population (Landolt et al. 1999). Thus, financing for a firm may draw, as in the case of Agustín's carpentry business, on savings from wage-work in the USA, or might involve pooling resources with migrant kin, as in the case of Carlos Antonio's bean exporting enterprise. Production is transnational when inputs are garnered through the border-spanning circuit. Olga Zelaya's restaurant, which gets its paper products printed in El Salvador, is a case in point. Likewise, Tomás Aguilar, the Los Angeles-based lawyer, 'produces' a transnational service, namely legal documents processed in the Salvadoran judicial system.

The distinction between transnational and local markets is much less clear-cut. In a narrow sense, a market is transnational when the product must cross national borders to be consumed. Among the cases described, the enterprises that clearly produce for a transnational market include Mr Aguilar's law office, Carlos Antonio's bean exporting business, Agustín's carpentry shop, and the Constancia bottling company. Two contrasting cases, where the market is local, are the restaurants of Olga Zelaya and Jaime García. Less easy to decipher is the case of Ana and José who run a restaurant and rent out their truck in the town of Santa Rita. While they provide generic goods and services for local consumers, clients' capacity to consume depends on a regular flow of remittances. In effect, the consumer market in Santa Rita is constituted by non-migrant members of transnational households.

The second dimension that distinguishes types of economic activities is their range and complexity, which is reflected in an enterprise's budget, ownership, workforce, and management structure. The discussion follows the types of economic activities identified in Figure 1.

Figure 1: transnational economic activities and enterprises

\begin{tabular}{|c|c|c|c|}
\hline & Range and complexity & El Salvador & Settlement cities \\
\hline \multirow[b]{2}{*}{$\begin{array}{l}\text { From } \\
\text { below }^{a}\end{array}$} & $\begin{array}{l}\text { Household oriented } \\
\text { activities }\end{array}$ & $\begin{array}{l}\text { - Remittances } \\
\text { - Real estate investments } \\
\text { - Pueblo stores }\end{array}$ & - Street vendors \\
\hline & $\begin{array}{l}\text { Medium scale } \\
\text { enterprise }\end{array}$ & $\begin{array}{l}\text { Transnational logic } \\
\text { - Return migrant businesses } \\
\text { - Export ventures } \\
\text { Expansion into transnational circuit } \\
\text { - Restaurants } \\
\text { - Retail sales (artesanía, food) }\end{array}$ & $\begin{array}{l}\text { - Restaurants } \\
\text { - Legal services } \\
\text { - Retail sales }\end{array}$ \\
\hline $\begin{array}{l}\text { From } \\
\text { above }^{b}\end{array}$ & Capitalist corporations & $\begin{array}{l}\text { Expansion into transnational circuit } \\
\text { - Manufacturing enterprises } \\
\text { - Banks }\end{array}$ & $\begin{array}{l}\text { Transnational logic } \\
\text { - Courier services } \\
\text { (Gigante Express) }\end{array}$ \\
\hline
\end{tabular}

a 'From below' suggests activities linked to the migrant household that involve a struggle for economic incorporation or political voice.

b From above alludes to practices that originate in existing structures of power, such as the state, as a response to migrants' transnational activities. 


\section{Patricia Landolt}

A first type of enterprise (household-oriented activities) includes transnational activities that require very little start-up capital, have no capacity for innovation or expansion, rely on the unpaid labour of family members, and contribute simply to the social reproduction of the transnational household. Ana and José, who set up small business ventures to guarantee an income in Santa Rita, are a perfect example of this type. Another example is a migrant who helps his mother or wife set up a little retail store in their hometown and supplies the store with merchandise from abroad. In the USA, a prime example of this type of activity is the street vendor who sells typical Salvadoran dishes. While the street vendor may prepare some of the food herself, she also purchases products from informal couriers or viajeros who bring goods from $\mathrm{El}$ Salvador once or twice a month. Small-scale transnational economic activities thus tend to fall within the informal economy of survival.

The second type of enterprise generates a return on its investment, has a formal management structure, may have some potential for innovation and expansion, and its labour force receives a wage and is not restricted to family members. This mid-scale type includes both enterprises conceived and developed within the transnational circuit, or established firms that seek to expand by inserting themselves in this circuit. In both cases, the entrepreneurs' transnational field of vision, cultivated through trips or long-term migration to the USA, contact with kin and friends abroad, and familiarity with migrant consumer patterns, is pivotal to the success of the enterprise.

Enterprises forged within the border-spanning circuit can be found in El Salvador and migrant settlements. Firms established in El Salvador, such as Agustín's carpentry shop and Carlos Antonio's bean exporting business, tend to rely on transnational financing and markets. Firms based in the USA, such as Olga Zelaya's restaurant and Mr Aguilar's LA-based law office, tend to garner production inputs from contacts in El Salvador. The statistical evidence also suggests that US-based migrant entrepreneurs are typically US citizens with at least a high school education (Landolt 2000).

In contrast, firms that have expanded into the transnational circuit are overwhelmingly based in El Salvador and focus largely on capturing the migrant market. An example is Jaime García's chain of restaurants. Indeed, a growing number of established, medium-size enterprises in El Salvador now market directly or indirectly to migrants. Firms are exporting to Salvadoran settlements in the USA and Canada, and advertising on the Internet. Some businesses have even been known to finance and negotiate a viajero's business visa, in exchange for which the informal courier commits to selling their product exclusively.

The third type of transnational enterprise includes large corporations with a proven capacity for capital accumulation. To date, although theoretically not restricted to this sector, the bulk of Salvadoran transnational capitalist enterprises have been firms owned by members of the Salvadoran bourgeoisie. Like the Constancia corporation, such firms have sought to capture the migrant market using a variety of expansion strategies. A range of Salvadoran enterprises, including several banks, food and footwear manufacturers, and a food mart, now have a sales office, representative, or distributor in Los Angeles and/or Washington, DC.

The few documented cases of Salvadoran transnational corporations founded by a migrant in the interstices of the transnational circuit are courier and remittance agencies. One such firm is Gigante Express, which was started in 1982 by a 
Salvadoran migrant, and is now the largest remittance agency in Central America. First based in Los Angeles, the small business began delivering packages from LA to El Salvador and now handles half of all remittances to El Salvador. The corporation has more than sixty agencies and operations in Canada, the United States, Guatemala, and Honduras. Ninety per cent of its customers across these different locations are Salvadorans (Orozco 2000). Other Salvadoran remittance agencies include Leon Express and Bony Express, both of which now face fierce competition from US-based courier agencies such as Western Union and MoneyGram.

The third dimension that distinguishes transnational economic activities is the character of the social network through which resources are mobilized and the sources of social capital that under gird these exchanges. First, transnational economic activities linked to household social reproduction mobilize meagre resources through a reduced social network, one that basically includes household members. Altruism, namely moral obligation, is the principle source of social capital under girding the exchange.

Secondly, the social networks of entrepreneurs with mid-scale business activities are commonly diverse and eclectic. On the one hand, entrepreneurs tap strategically into kinship and paisano ${ }^{9}$ networks to garner resources and support for their business. Thus, Agustín calls on extended family in different US cities to drum up clients, Carlos Antonio pools resources with his brother and a cantón compadre to start up the bean-exporting firm, and Luis Aguilar coordinates legal services with his non-migrant brother. Such resource exchanges are underlain by a sense of bounded solidarity with members of the extended family and/or paisanos and are mediated by enforceable trust. In other words, as will become clearer in the discussion of transnational social systems, there are larger transnational social structures that help ensure the stability of exchanges. Yet, mid-size transnational enterprises are not constructed solely on the basis of resources mobilized by virtue of membership in social networks. A binding contract between business partners, for example between Jaime García and his California-based associates or between the two Aguilar brothers, also frame resource transactions and commitments.

Similarly, the investment and expansion strategies of transnational corporations do not depend on the mobilization of resources underwritten by social capital to be constituted. Nonetheless, as seen in the case of Constancia, corporations encourage the formation of an informal network of contacts in the community and develop sales strategies that clearly respond to a distinctly migrant market (for example, a free phone card with purchase).

\section{Transnational social formations}

I introduce the concept of 'transnational social formations' in order to expand on the proposition that transnational institutions are contoured by the broader structures (Granovetter 1993) and locations (Guarnizo and Smith 1998) in which they are embedded. I define transnational social formations as complex, heterogeneous and relatively stable social structures that span national borders and in which interactions between actors are governed by an unspoken code of sanctions and rewards and/or a legal-political framework. Two types of configurations are discerned: (1) novel arrangements, such as the transnational social field that can be argued to emerge as a 
result of the back-and-forth movements of a migrant population; and, (2) locations, such as a neighbourhood or pueblo, that are incorporated into the circuits of transnational activities. The discussion identifies transnational locations associated with Salvadoran migration. In particular, it considers the ways in which different locations tend to concentrate certain types of economic activities, and how nominally similar economic ventures take on distinct forms depending on the locations in which they are embedded. ${ }^{10}$

In El Salvador, one obvious transnational location is the pueblo or what Levitt (2000) has termed transnational village. As Levitt (2000:7) explains,

Transnational villages arise when a large proportion of a relatively small community leaves a well-defined locale and settles near one another in a specific receiving-country neighbourhood or town. Non-migrants' economic dependence on remittances is high. At the same time, migrants also depend on non-migrants to bring up their children or to manage what land or properties they still own. Migrants and non-migrants tend to know one another or each other's families personally. Hence, they have a clear sense of bounded solidarity and a great capacity for exercising enforceable trust. In the receiving country and at home, their social lives continue to be so entwined with one another that those who do not send money to their families or do not 'do right' by the community feel the consequences.

In the USA, one can speak of transnational neighbourhoods, parks, and street corners, such as Pico Union and MacArthur Park in Los Angeles or Mount Pleasant in Washington, DC, in which the rhythm of life follows the beat of Salvadoran transnationalism. Historically established as points of entry and settlement for new arrivals, such locations characteristically concentrate Salvadoran entrepreneurial ventures and serve as spaces for formal and informal community gatherings. They also constitute part of the Salvadoran imaginary, as they are known by everyone and are often more familiar to transnational households than the capital city of $\mathrm{El}$ Salvador.

In El Salvador, urban and rural locations offer very different conditions for the formation of enterprise. For instance, in the transnational pueblo a few entrepreneurial households tend to monopolize investment opportunities. A single family may simultaneously run the local store, offer viajero services for the community, shuttling goods back and forth and procuring supplies for their store, and serve as the distribution and pick-up centre for cash remittances. The owners can comfortably run a monthly tab for any family that receives remittances, certain that they will cancel their bill in US dollars at the end of the month. In urban settings, such as San Salvador, transnational entrepreneurship does not have this synergistic effect. Urban viajeros, for example, cannot rely on a ready-made clientele of paisanos, but rather must build up a network of clients. Given competition from department stores and manufacturers, they also have little chance of setting up competitive retail stores simply on the basis of informal imports.

In the USA, the economic and political structures of each settlement city also occasion distinct economic motifs and institutional arrangements. First, the labour market structure of the two cities result in distinct migration patterns. Los Angeles, 
for example, has a much longer history of Salvadoran migration than DC that began in the 1940s when Salvadoran men were recruited to work in the city's shipping industry (Córdoba 1995). In contrast, migration to Washington, DC only began in the 1960s and was spearheaded by women informally recruited to labour in the houses of government technocrats (Repak 1995). As a result, the community of Los Angeles is larger and represents a broader regional and class spectrum of Salvadoran society than the population in Washington, DC A second significant difference is the ethnic composition of the two cities. The strong Latino presence in Los Angeles has allowed Salvadorans to achieve a great deal of political and social recognition. In contrast, Salvadorans have made few inroads into the African-American dominated power structure of Washington, DC.

Such contextual differences across the two locations produce distinct institutional arrangements. In DC entrepreneurs have been unable to consolidate any sort of business associations and have had infrequent contact with local business groups. In the absence of a representative organization, DC entrepreneurs simply struggle to survive in the local business environment while upholding transnational obligations that are by and large limited to a handful of hometown kin and friends.

In contrast, Los Angeles is home to two migrant-based business organizations that enable entrepreneurs to tap into a broader set of institutional contacts to advance their business interests. A first institution is the 80 member strong Salvadoran Chamber of Commerce of Los Angeles (SCC). The SCC was founded in the early 1990s under the tutelage of El Salvador's business community and with the support of the local consulate. It has since then become an independent organization that seeks to facilitate business loans and contacts for local migrant entrepreneurs. In 1998, a second independent organization was formed called the Political Committee for Central American Immigrants and Entrepreneurs in Los Angeles (Comité Político de los Emigrantes y Empresarios Centroamericanos en Los Angeles, COPEECA), which seeks to consolidate a political space and create economic opportunities for migrant entrepreneurs in El Salvador and the US. The COPEECA's membership includes both institutions and individuals in Los Angeles and El Salvador. To date, the COPEECA has met with leading figures in all of El Salvador's political parties and with the mayors of 20 municipalities across the country. It has also signed an agreement in principle with the mayor of San Salvador that, if successful, will allow migrant entrepreneurs to bid on the municipality's public works projects.

\section{The cumulative and unintended consequences of economic transnationalism}

The concept of cumulative consequences has a long and rather eclectic history. Thorstein Veblen, a founding thinker of institutional economics, is one of the first to use the concept of cumulative causation to suggest that institutions tend to be relatively invariant and their patterns of change self-reinforcing (Veblen 1899). The idea is furthered by Myrdal (1957) who suggests that 'a social process tends to become cumulative and often to gather speed at an accelerating rate' (Myrdal 1957: 13). Most recently, the term has been claimed by economic sociology in the guise of cumulative consequences. In its latest incarnation, the concept denotes the influence of past states on present conditions and emphasizes the social contexts that make 
spiralling towards a particular outcome possible (Portes 1995). A second related term is that of unintended consequences, which suggests that outcomes of action are often not those intended by actors and may in fact be the very opposite (Merton 1936).

In this case, refugee-migrants concerned with personal safety and economic security and simultaneously compelled to uphold household obligations in wartime forged transnational social networks that facilitated the flow of resources. From humble beginnings, a transnational frame of reference for economic insertion and mobility emerges and serves as the point of departure for economic strategies of social reproduction and entrepreneurship. Tracing the trajectory of different economic practices reveals a self-reinforcing transformatory path of cumulative and unintended consequences.

First, remittance transfers and household-oriented economic ventures transform families and communities. Households that receive remittances demonstrate tangible improvements in their standard of living. Remittance dollars grant access to education and health, and may permit a family to buy agricultural land or make improvements on an existing property. Remittances, combined with knowledge of wages and conditions in Salvadoran settlement cities, may also alter the labourer's relationship to the local economy. Weighing the value of their labour in transnational terms, workers have more leverage to reject the miserably low wages offered by Salvadoran employers. Entire communities are transformed, as enterprises, land holdings, and basic survival increasingly revolve around the remittance transfer. In turn, locations inserted in the circuits of Salvadoran economic transnationalism prosper relative to marginal, non-transnational locations, which remain mired in poverty. As they subsidize households and alleviate the worst forms of poverty, remittances finally have the unintended consequence of perpetuating a bankrupt economic system.

In the USA, migrants' economic commitment to transnational households circumscribes their social relations. Familial obligations erode a migrant's capacity to establish durable social relations with and fulfil commitments to non-household members. As a result, Salvadorans in the USA tend to have small and unstable personal networks that are prone to momentary collapses (Menjívar 2000). The financial commitment to transnational households clearly has the unintended consequence of undermining the formation of locally oriented social networks of support. The circulation of resources under girded by moral obligation thus has a downside (Portes and Landolt 1996).

Second, the evidence suggests that transnational migrant entrepreneurship facilitates and is part of the settlement process and not a step prior to incorporation. First, being a high school graduate and US citizen are key demographic predictors that increase the probability of transnational entrepreneurship (Landolt 2000). This is because citizenship grants the legal stability and physical mobility typically required to oversee transnational business ventures. Moreover, Table 5 suggests that transnational entrepreneurship is linked to higher than average earnings. Confirming the general poverty of the Salvadoran immigrant community, the bulk of respondents across occupational categories have an annual income of between $\$ 12,000$ and $\$ 24,000$. Yet, 40 per cent of transnational and local entrepreneurs have an annual income of between $\$ 24,000$ and $\$ 84,000$, as compared with only 5 per cent of wageworkers. ${ }^{11}$ 
Table 5: migrant annual incomes by occupational grouping

\begin{tabular}{lcccc}
\hline Annual income & $\begin{array}{c}\text { Transnational } \\
\text { entrepreneurs } \%\end{array}$ & $\begin{array}{c}\text { Local } \\
\text { entrepreneurs } \%\end{array}$ & $\begin{array}{c}\text { Workers } \\
\%\end{array}$ & $\begin{array}{c}\text { Total } \\
\%\end{array}$ \\
\hline Less than 6000 & 3.5 & 13.6 & 20.5 & 14.6 \\
$\$ 6-12,000$ & 13.5 & 20.5 & 34.7 & 26.7 \\
$\$ 12-24,000$ & 34.0 & 20.5 & 39.9 & 36.2 \\
$\$ 24-84,000$ & 39.0 & 40.9 & 4.9 & 19.0 \\
More than $\$ 84,000$ & 9.9 & 4.5 & & 3.5 \\
Total & 100.0 & 100.0 & 100.0 & 100.0 \\
$\mathrm{~N}$ & 141 & 44 & 268 & 453 \\
\hline
\end{tabular}

Source: Comparative Immigrant Enterprise Project, 1998

Third, as migrant remittances and transnational entrepreneurship transform the economic landscape of El Salvador they prompt both capital and state elites to reorient their economic strategies and/or policy programme. As discussed above, Salvadoran firms are expanding into the migrant market through a variety of strategies. Likewise, following the signing of the Peace Accords in 1992, the government has launched several programmes directed at the migrant population. In 1994, a new consulate-based programme began to offer legal services to undocumented Salvadorans and promoted the use of formal channels for remittance transfers. In 1999, the Salvadoran Foreign Ministry (relaciones exteriores) inaugurated the Office of Attention to the Migrant Community (Dirección General de Atención a la Comunidad en el Exterior).

The new office, which is modelled on Mexico's Programme for Mexican Communities Abroad (PCME), is the first coherent government project of social, cultural and economic engagement with the migrant population. Of particular interest, the Office of Economic Affairs (Dirección de Asuntos Económicos), a department within the office claims it will first, link the production of small and medium-size enterprises in El Salvador with the Salvadoran migrant market, secondly, use the migrant market as a stepping stone for capturing the US Latino market and finally, promote tourism in El Salvador. In effect, the government policy seeks to expand the scope of the existing strategy of Export Oriented Industrialization (EOI) to include both export-processing zones and tourism in El Salvador and the migrant market abroad. The effect of this new policy on migrant entrepreneurship is yet to be seen. The new programme certainly signals the consolidation of transnational entrepreneurship and migrant consumption as cornerstones of the national economy.

\section{Conclusion}

In this article I have explored two patterns of economic transnationalism. First, I have described how Salvadoran migrant households forge transnational social networks under adverse conditions in order to fulfil familial obligations and manage scarce resources. In the process, households have acquired a transnational field of vision that 
enables them to negotiate and take advance of the economic opportunities and constraints that result from their dual footing. As they straddle places of origin and settlement, migrant households are better able to organize their social reproduction, identify novel investment opportunities, and carve out new market niches.

Second, I have examined the nature of transnational entrepreneurship as it extends beyond the migrant population and envelopes El Salvador's entire business landscape. A wide spectrum of large- and medium-sized firms, many with a solid history of profit and success in the country, are currently reorienting their investment and expansion strategies to include migrant settlements. Likewise, the government of El Salvador has expanded its existing strategy of EOI to include the migrant market. In effect, transnational entrepreneurship and a transnational field of vision are no longer the exclusive purview of migrant entrepreneurs seeking economic incorporation. Its scope now includes both the government and business class of El Salvador with the result that economic transnationalism is being consolidated as the normative order of doing business for all Salvadorans.

The evidence presented in the article furthers two sets of theoretical discussions. The analysis draws on valuable insights from economic sociology and hence advances the frontiers of this field and confirms its relevance for the sociology of migration. First, the behaviour of Salvadoran migrants bears out that even economic pursuits are socially-oriented. The case study demonstrates, for instance, how the socially expected duration of a temporary migration contours a refugee exodus and the ways that social obligations to kin shape migrants' subsequent strategies of resource allocation. In effect, normative expectations mediate the individual migrant's calculations for survival and mobility.

Second, the typology of transnational enterprises reveals that the character of entrepreneur's social network and the sources of social capital that under gird resource exchanges is an important element that results in individual-level differences in economic practices. While household-oriented economic ventures mobilize meagre resources under girded by altruistic sources of social capital through restricted social networks, mid-scale entrepreneurs tap strategically into kin and paisano networks to mobilize a rich variety of resources mediated by both instrumental and altruistic sources of social capital. An unexpected finding highlighted by the case of Juan Segura and the Constancia corporation is that large Salvadoran firms are also beginning to recognize that market success in Salvadoran settlements rests in part on the capacity to forge sociability.

Third, the concept of embeddedness reveals the ways in which broad structural forces and the conditions provided by different locations contour the character of transnational practices and institutions. Thus, nominally similar forms of entrepreneurship take on distinct characteristics across the rural and urban settings of El Salvador. Likewise, in the United States differences in the class and regional composition of the migrant communities and in the types of institutions they are able to forge can be linked to the labour market structure and political terrain offered by the two settlement cities.

The article further contributes to scholarship on transnational migration. First, economic transnationalism emerges as part of a strategy of economic incorporation in which migrants negotiate obligations, restrictions and opportunities across national borders. Time does not cause Salvadoran migrants to give up their transnational field 
of vision or the economic options it confers. Indeed, successful mid-scale transnational entrepreneurs tend to be US citizens with a firm footing in the United States. Moreover, the above average earnings of entrepreneurs suggest that transnational resource management and investment can facilitate social mobility and economic advancement. Finally, the institutional responses of the Salvadoran government and capital elites are consolidating a transnational framework that encourages migrants' continued and long-term engagement in the economic affairs of their country of origin.

Second, the analysis of Salvadoran economic transnationalism problematizes the idea that contemporary migration processes are simply becoming deterritorialized. The evidence demonstrates that, despite the border-spanning nature of transnational practices, migrants are embedded in distinct households, communities, and locations that constrain the character of transnational activities and outcomes. In particular, the evidence highlights the paradoxical and complex nature of locations. While locations contextualize and mould transnational practices, they also emerge as a new type of transnational social formation, understood as a complex, heterogeneous and relatively stable social structure that spans national borders and in which interactions between actors are governed by an unspoken code of sanctions and rewards and/or a legalpolitical framework.

This case study offers rich insights into the border-spanning strategies of incorporation forged by a resource-poor migrant population. It also identifies the ways in which relatively humble economic strategies transform the business landscape of a sending country. The findings are relevant for a range of small nations of the periphery experiencing transnational migration, specifically the countries of the Caribbean Basin and the smaller nations of Southeast Asia with migration flows to the USA.

Patricia Landolt is at the Department of Sociology, University of Toronto, Scarborough, Ontario, Canada.

\section{Acknowledgements}

I thank Angelique Haugerud of Rutgers University, two anonymous reviewers, and the editors of the special volume for the many thoughtful comments and insightful observations they offered on earlier versions of this article.

\section{Notes}

1. The data on which this article is based were collected under grants from the National Science Foundation (SBR-9796286); Ford Foundation (\#960-0527); and Andrew W. Mellon Foundation. The contents are the author's exclusive responsibility.

2. Social capital is defined as the ability to secure resources by virtue of membership in social networks or larger social structures. Sources of social capital are distinguished by the presence/absence of overarching structures defining the character of the transaction. Altruistic sources include: (1) granting resources to others out of moral obligation; and (2) based on particularistic loyalties to members of the same territorial, ethnic, or religious community (bounded solidarity). Instrumental sources of social capital are also twofold: (1) face-to-face reciprocal transactions that carry the full expectation of commensurate return 


\section{Patricia Landolt}

by the benefited party (simple reciprocity); and, (2) resource transactions embedded in larger social structures that act as guarantors of full returns to donors either from the benefited party or the from community at large (enforceable trust) (Portes 1998).

3. The household is not a conflict-free unit with a singular set of coherent interests and strategies for social reproduction. Gender and generational struggles for power frame decisions about resource pooling, allocation and expenditure priorities. For a discussion of the gendered nature of transnational migration see Hondagneu-Sotelo and Avila (1997) and Mahler (1999).

4. Socially expected durations (SEDs) are 'collectively patterned expectations about temporal durations imbedded in social structures of various kinds. SEDs are to be strongly distinguished from actual durations ... and constitute a class of social expectations that significantly affect the behaviour of groups and individuals, and of those in their role-sets and organizational-sets ... and constitute a fundamental class of patterned expectations linking social structures and individual action' (Merton 1984: 265-6).

5. In 1990, the federal government's prejudicial treatment towards Salvadoran and Guatemalan asylum claimants prompted the American Baptist Church (ABC) to file a lawsuit against the state (namely Attorney General Thornburgh vs. American Baptist Church). The $\mathrm{ABC}$ won the case and the government agreed to grant new asylum hearings to Salvadorans and Guatemalans who had been in the country since 1990. In 1991, Temporary Protected Status (TPS), including the right to work, was granted to 187,000 undocumented Salvadorans for the period up to June of 1992. In 1994, the period for TPS was extended to December of 1994 under a 'deferred enforced departure' (DED) agreement (Stanton-Russell 1995).

6. Names of people and places have been changed.

7. El Salvador is divided into 226 municipios. Each municipio has a municipal capital (cabecera municipal) and a handful of cantones. Cantones have historically been very poor rural areas.

8. Compadre (co-father) is a term that originates with the institution of compadrazgo (godfatherhood) and refers to adults obligated to assist a newborn child and his or her parents. The term is also used to refer to trustworthy friends that one can turn to in times of great need.

9. Paisanos are individuals from the same place of origin.

10. For an analysis of the Salvadoran transnational social field see Lungo (1997), Mahler (1998), and Landolt et al. (1999).

11. Local entrepreneurs manage enterprises whose profitability does not depend on the maintenance of regular links or exchanges with El Salvador. Transnational entrepreneurs, in contrast, maintain regular contact with El Salvador to sustain their business venture.

\section{References}

Aguayo, S. and P. Weiss Fagen (1988) Central Americans in Mexico and the United States, Washington, DC: Hemispheric Migration Project and CIPRA at Georgetown University.

Basch, L., N. Glick Schiller, and C. Szanton-Blanc (1994) Nations unbound: transnational projects, postcolonial predicaments and deterritorialized nation-states, Amsterdam: Gordon and Breach.

Caribbean Update (1996) 'El Salvador: balance of payments on target', 1 October.

Córdoba, C. (1995) 'Central American migration to San Francisco: one hundred years of building a community', in Central Americans in California: transnational communities, economies and cultures, Los Angeles: Center for Multiethnic and Transnational Studies, University of Southern California, 5-21. 
Daniels, R. (1990) Coming to America: a history of immigration and ethnicity in American life, New York: Harper Collins.

Edwards, B. and G. T. Siebentritt (1991) Places of origin: the repopulation of rural El Salvador, Boulder, CO: Lynne Rienner Publishers, Inc.

Ferris, E. (1987) The Central American refugees, New York: Praeger Press.

Foner, N. (1997) 'What's new about transnationalism? New York immigrants today and at the turn of the century', Diaspora 6, 355-75.

Glick Schiller, N., L. Basch, and C. Blanc-Szanton (eds.) (1992) Towards a transnational perspective on migration: race, class, ethnicity, and nationalism reconsidered, New York: New York Academy of Sciences, 1992.

Gosse, V. (1988) 'The North American front: Central American solidarity in the Reagan era', in M. Davis and M. Sprinker (eds), Reshaping the US left: popular struggles in the 1980s, New York: Verso Books, 11-50.

Granovetter, M.S. (1985) 'Economic action and social structure: the problem of embeddedness', American Journal of Sociology, 19, 481-510.

Granovetter, M.S. (1993) 'The nature of economic relationships', in R. Swedberg (ed.) Explorations in economic sociology, New York: Russell Sage Foundation, 5-35.

Guarnizo, L. E. and M. P. Smith (1998) 'The locations of transnationalism', in M. P. Smith and L. E. Guarnizo (eds), Transnationalism from below, New Brunswick, NJ: Transaction Publishers, 3-34.

Harvey, D. (1989) The condition of postmodernity: an enquiry into the origins of cultural change, Oxford and Cambridge, Ma.: Blackwell.

Held, D., A. McGrew, D. Goldblatt, and J. Perraton (1999) Global transformations: politics, economics and culture, Cambridge: Polity Press.

Hondagneu-Sotelo, P. and E. Avila, (1997) 'I'm here, but I'm there: the meanings of Latina transnational motherhood', Gender and Society, 11, 548-71.

Kearney, M. (1995) 'The local and the global: the anthropology of globalization and transnationalism', Annual Review of Anthropology, 24, 547-65.

Itzigsohn, J. (2001) 'Immigration and the boundaries of citizenship: the institutions of immigrants' political transnationalism', International Migration Review, 34, 1126-54.

Jones, M. (1976) The Old World ties of American ethnic groups, London: Macmillan.

Landolt, P. (2000) The causes and consequences of transnaitonal migration: Salvadorans in Los Angeles and Washington, DC. Ph.D. dissertation, Department of Sociology, Johns Hopkins University, Baltimore, MD.

Landolt, P., L. Autler and S. Baires (1999) 'From Hermano Lejando to Hermano Mayor: the dialectics of Salvadoran transnationalism', Ethnic and Racial Studies 22, 290-315.

Levitt, P. (2000) 'Transnational migration and development: a case of two for the price of one?' Working Paper, Princeton, NJ: Center for Migration and Development.

López, D., E. Popkin, and E. Telles (1997) 'Central Americans: at the bottom, struggling to get ahead', in R. Waldinger and M. Bozorgmehr (eds.), Ethnic Los Angeles, Newbury Park, CA: Russell Sage Foundation Press, 26-40.

Lungo, M. (1997) Migración internacional y desarrollo, volumes 1 and 2, San Salvador: FUNDE.

MacEoin, G. (ed.) (1985) Sanctuary: a resource guide for understanding and participating in the Central American refugees' struggle, San Francisco: Harper and Row.

Mahler, S. (1995) American dreaming: immigrant life on the margins. Princeton, NJ: Princeton University Press.

Mahler, S. (1998) 'Theoretical and empirical contributions toward a research agenda for transnationalism', in M. P. Smith and L. E. Guarnizo (eds), Transnationalism from below, New Brunswick, NJ: Transaction Publishers, 65-100. 


\section{Patricia Landolt}

Mahler, S. (1999) 'Engendering transnational migration: a case study of Salvadorans', American Behavioral Scientist, 42, 690-720.

Massey, D., J. Arango, G. Hugo, A. Kouaouci, A. Pellegrino and J. E. Taylor (1998) Worlds in motion: understanding international migration at the end of the millennium, Oxford: Clarendon Press.

Menjívar, C. (2000) The ties that unbind: Salvadoran immigrants and the transformation of social networks, Berkeley: University of California Press.

Merton, R. (1936) 'The unanticipated consequences of purposive social action', American Sociological Review, 1, 894-904.

Merton, R. (1984) 'Socially expected durations: a case study of concept formation in sociology', in W.W. Powell and R. Robbins (eds) Conflict and consensus: a festschrift for Lewis A. Coser, New York: The Free Press, 262-86.

Merton, R. (1995) 'Preface', in Alejandro Portes (ed.) The economic sociology of immigration, New York: Russell Sage, v-xx.

Myrdal, G. (1957) Rich lands and poor, New York: Harper and Row.

Nash, J. and P. Fernández-Kelly (1983) Women, men, and the international division of labour, Albany, NY: State University of New York Press.

Orozco, M. (2000) 'Remittances and markets: new players and practices', Working Paper Series, Washington, DC and Claremount, CA: Inter-American Dialogue and Tomás Rivera Policy Institute.

Popkin, E. (1999) 'Guatemalan Mayan migration to Los Angeles: constructing transnational linkages in the context of the settlement process', Ethnic and Racial Studies, 22, 267-89.

Portes, A. (1995) 'Economic sociology and the sociology of immigration: a conceptual overview', in A. Portes (ed.) The economic sociology of immigration: essays on networks, ethnicity, and entrepreneurship, New York: Russell Sage Foundation, 1-41.

Portes, A. (1998) 'Social capital: its origins and applications in modern sociology', Annual Review of Sociology, 24, 1-24.

Portes, A. (1999a) 'Conclusion: towards a new world - the origins and effects of transnational activities', Ethnic and Racial Studies 22, 463-77.

Portes, A. (1999b) 'Globalization from below: the rise of transnational communities', in Don Kalb (ed.) The ends of globalization: bringing society back in, Boulder, CO: Rowman and Littlefield Publishers, 253-70.

Portes, A. and J. Sensenbrenner (1993) 'Embeddedness and immigration: notes on the social determinants of economic action', American Journal of Sociology, 98, 1320-50.

Portes, A. and P. Landolt (1996) 'The downside of social capital', The American Prospect, 26, $18-22$.

Portes, A. and R. G. Rumbaut (1996) Immigrant America: a portrait, Berkeley, CA: University of California Press.

Portes, A., L. E. Guarnizo and P. Landolt (eds) (1999a) Special Volume on Transnational Migrant Communities, Ethnic and Racial Studies, 22, 2.

Portes, A., L. E. Guarnizo, and P. Landolt (1999b) 'The study of transnationalism: pitfalls and promise of an emergent research field', Ethnic and Racial Studies, 22, 217-37.

Repak, T. (1995) Waiting on Washington: Central American workers in the nation's capital, Philadelphia, PA: Temple University Press.

Rouse, R. (1991) 'Mexican Migrants and the Social Space of Postmodernism', Diaspora 1, 823.

Sassen, S. (1991) The global city: New York, London, Tokyo, Princeton, NJ: Princeton University Press.

Sassen, S. (1996) Losing control? Sovereignty in an age of globalization, New York: Columbia University Press. 
Singleton, R., B. C. Straits and M. M. Straits (1993) Approaches to social research, New York: Oxford University Press.

Sklair, L. (1999) 'Competing conceptions of globalization', Journal of World-Systems Research, 5, 141-59.

Stanton Russell, S. (1992) 'Migrant remittances and development', International Migration, 30, $267-87$.

Stanton-Russell, S. (1995) 'Migration patterns of US foreign policy interests', in M. S. Teitelbaum and M. Weiner (eds) Threatened peoples, threatened borders: world migration and U.S. policy, New York and London: W. W. Norton and Company, 39-87.

Veblen, T. (1899) The theory of the leisure class: an economic study of institutions, Amherst, NY: Prometheus Books.

Vertovec, S. (1999) 'Conceiving and research transnationalism', Ethnic and Racial Studies, 22, 447-62.

Vilas, C. (1995) Between earthquakes and volcanoes: market, state, and the revolutions in Central America, New York: Monthly Review Press.

Wood, C. C. (1981) 'Structural changes and household strategies: a conceptual framework for the study of rural migration', Human Organization, 40, 338-44.

Zolberg, A., A. Suhrke, and S. Aguayo (1989) Escape from violence: conflict and the refugee crisis in the developing world, New York and Oxford: Oxford University Press. 